\title{
Effectiveness of Practical Work on Students' Achievement in Science at Secondary Level in Gorkha District Nepal
}

\author{
Kamal Prasad Koirala \\ Lecturer, Tribhuvan University, Gorkha Campus, Gorkha, Nepal \\ Ph.D Scholar, Tribhuvan University, Graduate School of Education, Nepal \\ Email: koiralakamal36@gmail.com
}

\begin{abstract}
This paper explores the effect of practical work on students' achievement in science at secondary level in Gorkha district, Nepal. The research was carried out using Quasi-Experimental pretest/ posttest research design. For carrying out the research, two schools of Gorkha district were selected purposively. For the collection of data, the researcher developed test items as the main instrument. Items were selected by analyzing difficulty level and discrimination index through pilot study. Then prepared test items were pretested to both schools and responses were checked and scored the result of pretest. The experiment group was taught using practical approach for one term while the control group was taught using the traditional methods. At the end of instructional period, both groups were post-tested with the same set of the test items in each school. The result of pre-test and post-test of both groups were analyzed at 0.05 level of significance using SPSS version 20 for the score of achievement test to find out the significance difference between two mean score of control group and experimental group. This study showed that mean achievement score of students taught by using practical approach resulted higher students achievement score of students in science. This study also revealed that the practical approach is more effective in science teaching at secondary level. So science teachers should be encouraged to incorporate this method in teaching.
\end{abstract}

Keywords: Quasi-experimental, student achievement, science teaching, practical work, quantitative research

\section{Background of the Study}

Practical work is an essential part of science education. In science lessons, we are trying to extend students' knowledge of the natural world and develop their understanding of the ideas, theories and models that scientists have found (Abraham \& Millar, 2009). Practical work is seen as an essential part of teaching and learning science at school level (Hodson, 2005; Abraham \& Millar, 2008). Students seem to enjoy practical work and it is thus generally regarded as adding to the students' motivation to study science at school level. In most countries, practical approach is either considered a central part of science classes or its status is wished to be lifted to such a position (Hodson, 2005). Practical work may be considered as engaging the learner in observing or manipulating real or virtual objects and materials (Millar, 2004). Practical work induces scientific attitudes, develops problem solving skills, collaboration and improves conceptual understanding in students (Okwoduba \& Okigbo, 2018). Practical work puts the students at the center of science learning where they can participate in, rather be told about science (Abrahams, \& Saglam, (2010). It focuses on observation, experimentation and manipulation of object/ materials being studied, and other scientific activities are performed by laboratory method as a part of practical work (Isozaki, 2017) which emphasizes heuristic learning.

Science teaching is a pedagogical approach used in science classroom whereby teaching and learning is approached with the same rigor as science itself (Abraham \& Millar, 2009). It is a process in which students are actively engaged in learning. It may include inquiry based learning, cooperative learning or student-centered learning (Ahmad, 2009; Isozaki, 2017; Abraham \& Millar, 2009). Practical method is an effective method in science teaching. It is also called an experimental method through which student can learn easily (Okwoduba \& Okigbo, 2018). Practical work is seen as an essential part of teaching and learning science at secondary level. Students seem to enjoy practical work and it is thus generally regarded as adding to the students' motivation to study science (Hodson, 1990). Scientific phenomena 
are such that they cannot be fully understood without practical work. So practical method is the best way for teaching science at secondary level (Kalra \& Gupta, 2012).

Science and technology is going towards the optimum stage. However, in Nepal many people have less knowledge on science and the proper use of technology due to the lack of proper science education. Due to the lack of practical approach, science teaching is not being effective in Nepal. Gorkha district is also not an exception from this problem. According to district education office, School Leaving Certificate [SLC] examination record of Gorkha district shows that second largest students fail in science at SLC in Gorkha district (field visit of DEO Gorkha, 2074). This scenario shows a challenge to teach science subject in an effective way by using practical approach. By the practical approach student can get deep knowledge and skills on science and technology as well as the new innovation of science (Okwoduba \& Okigbo, 2018; Sood, 1989). Similarly, students will be able to solve daily life problem by using the scientific method, and also increase the student achievement in science which ultimately help to increase the result of Gorkha district. So, effective practical approach is needed for science teaching. The practical approach is considered as an effective way of teaching for science education which increases the students' achievement and knowledge in science (Davar, 2012; Mohan, 2010). This study attempts to find out the effectiveness of practical approach in teaching. In the context of Nepalese school system, science curriculum has allotted 25 percent weightage for practical work and 75 percent for theoretical knowledge which seems not to be sufficient for practical work.

At the secondary level, if we teach science in a practical way, the student progress will be increased and student learn in-depth about science and scientific process. Practical approach means the student's own self-participation on practical work under the instruction of teacher and getting knowledge about experimental process, equipment or materials which are used for practical work. The teaching learning activities are very effective and long lasting through practical approach, so that it could be best for science teaching at secondary level. In the context of Nepal, practical approach is best for improving the progress of students in science subject. So, I tried to investigate about effect of practical work in science achievement at secondary level students in Gorkha Municipality of Gorkha district.

\subsection{Statement of the Problem}

The purpose of the study is to find out how effective the practical approach is for science achievement at secondary level. Most of the science teachers are found to use theoretical method while teaching science in the classroom. As a result, students feel science as a difficult subject, it is not possible to study by low status students, and are not able to achieve knowledge and skills about science as our expectation. The study focused on how to improve the students' achievement on science subject. So it is needed to be discovered that the practical approach is better for science teaching at secondary level. Such studies show that the practical approach is better for teaching to increase the student achievement and knowledge. Furthermore, this study attempts to establish the comparison between practical and theoretical method. For the teaching and learning activities of science at school level, teachers have to face different problems to do practical work for the students. So, they were intended to explore the effect of practical approach and way of improving it in science teaching. For this study, I chose Gorkha Municipality of Gorkha district because most of the study carried out in town area. Gorkha Municipality is located in rural area. Achievement of teaching learning of town area's students is always better than rural area. So I wanted to study why rural area students achievement is always low and how much effective the practical approach in rural areas is on students' science achievement.

\subsection{Hypothesis of the Study}

Hypotheses formulated for this study were as follows:

a) Null Hypothesis ( $\mathrm{H} 0): \mu_{1}=\mu_{2}$

There is no significant difference between mean achievement scores of students in science using practical work and without using practical work.

b) Alternative Hypothesis ( $\mathrm{H} 0): \mu_{1} \neq \mu_{2}$

There is significant difference between mean achievement scores of students in science using practical work and without using practical work. 


\subsection{Review of Literature}

From various literature studies, it has been concluded that the practical method is effective for science teaching. If we apply the practical method in secondary science teaching, it can improve the student's achievement or outcomes in science subject, and then students can know about new technology and innovation of the world and helps to use the scientific method in daily life. The curriculum also focuses to use the local instructional material and lesson planned teaching. Similarly, for the purposeful practical work teacher and student co-operation is very necessary. According to John Dewey, the practical method is based on "learning by doing" (Kalra \& Gupta, 2012). In this method, students actively participate in the practical work. It is the student centered method, so it increases the student involvement, creativity and explores the knowledge and technique about the science and technology (Sood, 2012). The practical method develops the physical, mental and psychomotor skill of the student. "I hear: I forget, I see: I remember, I do: I understand", these themes also focus to the practical method (Ahmad, 2009; Mohan, 2010).

The practical work is based on the Skinner's operant conditioning theory also. In this theory, if the learners actively participate in the field, they get more and more knowledge and experience. So the practical work may be effective, useful and fruitful for science teaching (Shrestha, Tamang \& Basnyat, 2066). According to Mohan (2010), students learn 10 percent from reading, 20 percent from hearing, 30 percent of what they see, 50 percent of what they hear and see, 70 percent of what they say and 90 percent of what they say and do. This also indicates that more knowledge is obtained from the work, so practical work is very effective for science teaching. For increasing the student's achievement in science the Curriculum Development Center makes the audio video aids course content which is very useful for practical teaching while the real objects are absent (Sharma, 2010). The Internet is very necessary in each school for searching the related audio video aid. In this modern and technological time, the multimedia communication technology is very useful and effective for searching the related audio video aids about the course content (Ahmad, 2009). The information and communication technology gives the knowledge about the modern technology and modern society (Kalra \& Gupta, 2012). The local low cost and no cost instructional materials are very effective for science teaching. The local and real materials increase the student daily life experience which can easily be collected from the local area. The local material like wood, stone, plant animal, bottle, newspaper, and metal pieces etc. are low cost and no cost material which can be used in practical method of science teaching (Sharma, 2010).

The third theory on which the study is anchored on is the Cognitive development theory by Bruner (1962). According to him, the goal of education should be intellectual development and not memorization of facts. He insisted that learning should entail the acquisition of the process of knowledge but not mere memorization of facts. Instruction should therefore teach the learner how to participate in the process that makes possible the establishment of knowledge (Sharma, 2010).

Bruner advocated organizing concepts and learning by discovery. He believed that learners can construct knowledge by interacting with the world around them. He identified three stages of cognitive development, the enactive, iconic and symbolic representations. Enactive is the representation of knowledge through actions while iconic is the visual summarization of images. The last one is the symbolic representation, which is the use of words and other symbols to describe experiences (Mohan, 2010).

Bruner believed that all learning occurs through the above stages. He believed that learning should begin with direct manipulation of objects. It should be followed by construction of visual representations, such as drawing a shape or a diagram. Finally, a learner understands the symbols associated with what they represent. The theory is applicable in this study because it advocated learning through a process (Kalra \& Gupta, 2012). The process of acquiring skills in science is a process. The current study advocated that the science process skills should be evaluated because it is through the processes that the learner acquires knowledge but not the end product - the results. According to Brunner, the process of knowledge acquisition is more important than the product (Sharma, 2010).

Constructivism is a fourth major learning theory, and is particularly applicable to the teaching and learning of science. Piaget suggested that through accommodation and assimilation, individuals construct new knowledge from their practical experiences. Constructivism views learning as a process in which students actively construct or build new ideas and concepts based upon prior knowledge and new information through practical method (Ahmad, 2009; Sood, 1989). The constructivist teacher is a 
facilitator who encourages students to discover principles and construct knowledge within a given framework or structure (Ahmad, 2009; Kalra \& Gupta, 2012). Therefore, constructivism supports the practical method on science teaching.

Pragmatism is also another major learning theory of practical science teaching. It is the product of practical experiences of life. Pragmatism means action, from which the word practical is derived. Pragmatists are practical people. They face problems and try to solve the problems from practical point of view. The central theme of pragmatism is activity or practical. The emphasis of pragmatism is on action rather than on thought. Thought enlarges its scope and usefulness by testing on practical issues. Since pragmatism advocates the experimental method of science, it is also called experimentalism thus stressing the practical significance of thought (Sood, 1989). It makes learning purposeful and infuses a sense of reality in science education. It makes schools into workshops and laboratories. It gives an experimental character in science education. Pragmatism makes man optimistic, energetic and active and also gives himself - confidence. The child creates values through his own activities. Hence practical method is more effective on science teaching according to pragmatism (Bhattarai, 2066 B.S).

\section{Methodology}

This section focuses on addressing research design, location of the study, target population, sample size and sampling procedures, research instruments, pilot study, data collection methods and procedures and methods of data analysis.

In quantitative methods, two research paradigms - positivism and post-positivism - are most popular (Muijs, 2012). Auguste Comte was the father of positivism and its dominant was on scientific research paradigm of natural science and to some extent, to social sciences until the mid 20th century (Chalmers, 1982). It tests the theory and hypothesis to find the reality (ontology) (Muijs, 2012). Experimental and evidence based fact are truth. It does not believe human thoughts and ideas because they are not directly testable. The epistemology of positivist paradigm is objectivity (Creswell, 2009). Quantitative epistemology means how to search the knowledge, ways of finding out the knowledge, which follow the quantitative research methodology used in experimental research where random sampling, pre-test and post tests, is administered in experimental and control group (Creswell, 2009; Muijs, 2012).

This study adapted a quasi-experimental pretest-posttest design (Creswell, 2012). There was one school from category A and one from category B. Each category had one experimental and one control group making two groups. The two groups set for the pre-test achievement were tested at the start of the study. The experimental groups were then taught using the practical approach while the control groups were taught using the conventional method. This was done for one week. Then the post-test achievements tests were administered and the results were analyzed by using the statistical tools.

Table 1. Design of the study

\begin{tabular}{llll}
\hline Group & Pretest & Treatment & Posttest \\
\hline Experimental & $\mathrm{T}_{1}$ & With practical approach & $\mathrm{T}_{2}$ \\
Control & $\mathrm{T}_{1}$ & Without practical approach & $\mathrm{T}_{2}$ \\
\hline
\end{tabular}

where,

$\mathrm{T}_{1}=$ Pretest given to the students

$\mathrm{T}_{2}=$ Posttest given to the students

Experimental $=$ randomly selected experimental group

Control $=$ randomly selected control group

For this study, two homogenous groups were prepared before the treatment. One group was considered as experimental group and the other group was considered as control group. The experimental group was taught by using practical approach and control group was taught without using practical approach.

All 24 public and private secondary school of Gorkha Municipality and their secondary level students and teachers were the population of this study. All the population or all the respondents were not possible to include in the research. So in this research, researcher purposively selected two public 
secondary schools of Gorkha Municipality of Gorkha district having same geographical location, nearly equal economic and social performance, physical structure and achievement in science (This ensures the homogeneity of the sampled schools) situated in district headquarters for convenience of the study and their teachers and students were selected randomly.

Table 2. The name of the selected two public schools and sample size

\begin{tabular}{lllll}
\hline S. N. & Name of the school & Address & Group & Sample size \\
\hline 1 & Mahendra Jyoti Sec. School & Gorkha Municipality-6 & Experimental & 20 \\
2 & Shakti Secondary School & Gorkha Municipality-6 & Control & 20 \\
\hline
\end{tabular}

The main instrument to be used in this study for data collection was achievement test which measured what an individual learned his or her present level of performance.

\subsection{Piloting of the Instrument}

For standardization of the constructed test, the researcher piloted the test in Balmandir Secondary School at chhahare Gorkha, which was not included in my sample. The test item was subjective type. The time taken by each student to complete the test and mean time to complete the whole test was found to be one hour and thirty minutes.

\subsection{Validity of Tools}

To insure the good quality of those tests, content validity is more important. It means that the test must have the test items which truly assess the skills and abilities as indicated by the given learning outcomes. There were ways of ensuring content validity of that achievement test. The researcher provided curriculum, textbook, teacher's guide and specification grid of secondary level of class nine to prepare achievement test paper for science teachers. School's subject teacher having ten year science teaching experience helped to develop this paper. Questions were developed including different level i.e. knowledge (20\%), comprehension (35\%), application (24\%) and higher ability (21\%). This achievement test paper was administered after consulting with subject expertise.

\subsection{Phases of the Experiment of the Study}

Pre-experimental phase: At this phase researcher selected two schools and made two homogeneous groups, one of them was taken as experimental and another was taken as control group. Then researcher constructed question of class nine. The tool was constructed according to the guidance of the subject experts. They were standardized by piloting at other school. At last, pretest was taken in both experimental and control group.

Experimental phase: At this phase the related science teachers taught selected science course of class nine in both experimental group and control group. The experimental group was taught by using practical approach and the control group was without it.

Post experimental phase: The achievement test was administered. The mean achievement, standard deviation, variance t- value were calculated.

\subsection{Data Collection Procedure}

The study was based on primary data. The study was delimited to the students of class nine. Two public schools were selected purposively from Gorkha Municipality of Gorkha district. Achievement test was conducted by separating two groups of students. Achievement test was the main tool for data collection to achieve the objective of the study. The primary data for this study was collected by administering pretest and posttest. Pretest was administered before teaching without practical method and posttest was administered after teaching with practical approach. Twenty students with ten boys and ten girls were selected from each school for carrying out the research. Students of Shakti Secondary School were taken as control group and students of Mahendra Jyoti Secondary School were taken as 
experimental group. During the period of pre test and posttest, the extraneous variables such as subject variables (gender, age, intelligence, ethnic group etc.) and environmental variables (time of day, size of classroom, noise level, period duration etc.) were controlled as far as possible.

\subsection{Methods of Data Analysis}

The collected data were analyzed and interpreted by using statistical test by giving critical appraisal using the following procedures. To analyze the obtained data the researcher used descriptive analysis also.

i. Mean, standard deviation and variance were calculated from the obtained marks using SPSS version 20 of each experimental and control group of the pretest and posttest respectively.

ii. T-test used at 0.05 level of significance for the score of achievement test to find the significance difference between two mean score of pretest and posttest by using SPSS version 20.

\section{Result}

This was an experimental study having two groups, experimental and control group. The main focus of this study was to explore the effectiveness of the use of practical approach in achievement of science. Achievement test was the main tool for data collection to achieve the objective of the study. The main parameter to explore the effectiveness of teaching approach is performance or achievement of the students. For this purpose score obtained from achievement test was collected. This statistical analysis of obtained data has been presented as a result. The result is mainly divided into two sections "comparision of pretest and comparision of posttest result" respectively.

Table 3. Comparision of pretest scores obtained by experimental group and control group before treatment

\begin{tabular}{lllllll}
\hline \multicolumn{7}{c}{ t-test } \\
\hline Group & Sample Size & Mean & S.D. & Variance & t-value & Remarks \\
\hline Experimental & 20 & 19.1 & 5.26 & 27.69 & 0.79 & \\
Control & 20 & 17.8 & 5.07 & 25.76 & & \\
\hline
\end{tabular}

The table shows the mean, standard deviation and variance of the scores in pre test of the experimental and control group are 19.1, 5.26, 27.69 and 17.8, 5.07, 25.76 respectively. For null hypothesis of the study, the researcher formed two groups of students as possible as homogeneous by random sampling method and divided into experimental and control group with the help of lottery. The objectives of the pretest were to find out the gap between two groups. The two tailed t-test used to ascertain that the difference between those two group were statistically significant or not. Since the calculated t-value was 0.79 to 0.05 level of significance at 38 degree of freedom, this shows that calculated t-value is less than the tabulated t-value 1.96 (ie $0.79<1.96$ ) which did not exceed the tabulated value or critical value. Thus the null hypothesis was accepted and alternative hypothesis was rejected. It indicates that there is no significant difference between the mean acheivement score of experimental and control groups on pretest. Therefore, the researcher concluded that both of the above groups were not significantly different.

Table 4. Comparison of posttest scores obtained by experimental and control group after treatments

\begin{tabular}{lllllll}
\hline \multicolumn{7}{c}{ t-test } \\
\hline Group & Sample size & Mean & SD & Varience & t-value & Remarks \\
\hline Experimental & 20 & 23.4 & 6.11 & 37.4 & 2.67 & \\
Control & 20 & 18.5 & 5.49 & 30.15 & & \\
\hline
\end{tabular}

From the table, mean, standard deviation and variance of the scores in pre test of the experimental and contrrol group are 23.4, 6.11, 37.4 and 18.5, 5.49, 30.15 respectively. And also it indicates that the mean, standard deviation and variance of both groups are different. 
In order to test null hypothesis of the study, the researcher used experimental treatment for experimental group and conventional treatment for control group. On completion of experimental period, the researcher administered posttest. The purpose of the posttest was to find out the gap between two groups. The two tailed t-test used to ascertain that the difference between those two groups were statististically significant or not. Since the calculated t-value was 2.67 at 0.05 level of significance at 38 degree of freedom, this shows that calculated t-value is greater than the tabulated t-value 1.96 (ie. $2.67>$ 1.96) which exceeded the tabulated or critical value. Thus, the null hypothesis was rejected and alternative hypothesis was accepted. It incdicates that there is significant difference between the mean acheivement scores of experimental and control groups on posttest. The experimental group seemed to be more consistent than the control group. Therefore, the researcher concluded that both of the above groups were significantly different.

\subsection{Comparision of the Effectiveness of the Use of Practical Method in Teaching Science between Experimental and Control Group}

To measure the effectiveness of the use of practical method in teaching science between experimental and control groups, the researcher intended to answer the question 'Is the use of practical method effective for science teaching?' Does the achievement differ significantly when practical method are used? The desire of the research study was to explore the effectiveness of practical method in teaching science and to compare the acheivement of student with using and without using practical method. In order to answer the research question and to fulfill the desire objectives of this study groupwise mean, SD and varience were calculated from obtained marks. The mean achievement score of experiment and control group were 23.4 and 18.5 respectively over full marks 45 in posttest. There is significant difference between the mean acheivement score of experimental and control group teaching with practical method and with experimental materials. Thus, the researcher concluded that the students of experimental group learn more adequately the topic of physics, chemistry and biology than the control group. The experimental group seemed to be more consistent than the control group. Boys and girls of experimental group were equally benifitted cognizing the concept of science when taught by using practical methods caused better acheivement than without using practical method. So, the teaching science with the use of practical method is more effective.

\section{Discussion of Findings}

From the sample school the researcher took twenty students of grade nine as control group and twenty students as sample for the experiment. Sample students were equally divided in experimental and control group homogenously as far as possible by the researcher on the basic of pretest result. To find the validity and reliability of achievement test (main tool of the research) the researcher took pilot test, then item analysis was done so that the researcher modified the question of the achievment test and administrated it as pretest on both groups of students before giving the treatment. The main purpose of pretest was to find the gap between two groups. The researcher calculated mean standard deviation and variance in both groups of students with their obtained marks. T-test uses at 0.05 level of significance at 38 degree of freedom to find the significance between experimental and control group based on the pretest result. The researcher experimentally concluded that both group students' achievement were not significantly different.

Then, experiments started in order to conduct the experimental study on effectiveness of practical approach of teaching science at grade nine. The researcher himrself developed the teaching lesson of chemistry in which each lesson consisted specific materials used for experimental group but specific materials has no use for control group. Experimental group was taught by different practical approach such as demonstration, field visit, disscussion, project work etc. but control group was taught by traditional method. Then, a standardized achievement test was administrated on both groups. The researcher calculated mean, standard deviation and variance on both groups with their obtained marks. T-test used at 0.05 level of siginificance at 38 degree of freedom to find the significance difference between experimental group and control group based on posttest. The researcher concluded that both 
groups were significantly different. Thus it is concluded that teaching science by using practical approach cause better achievement than without using practical method.

The existing statistical analysis of the data leads towards the following result as the major findings of this study. In fact the achievement of the student of experimental group taught by practical approach was positively very higher than the student of control group taught by traditional lecture method from the different analysis and statistical calculation such as mean, standard deviation and variance. The achievement of grade IX students who were taught science with using practical approach achieved better result than students who were taught without using practical approach. While using the practical approach in science teaching there were found various types of problems, that were there was no practical lab. Due to the weak economical conditions of school, they could not manage the practical materials of science, concept of practical method consume long time, lack of teachers' knowledge about the practical work, lack of teacher and students interest on practical work, less safety measures are used in practical lab, irregularities of teachers and students, lack of motivation of student on practical work, not well support of administration, theoretical subject matter and curriculum.

\section{Conclusion}

On the basis of findings of the study, review of the related literature and analysis of effectiveness of practical approach in science teaching; following conclusion has been drawn about effectiveness of practical approach in teaching science at grade nine.

The researcher found that the mean achievement score of the students taught with using practical approach is higher than the mean achievement score of student taught without using practical approach. The student of experimental group learn more adequately the science topics than the control group. The experimental group seemed to be more consistent than the control group. Boys and girls of experimental groups were equally benifitted cognizing the concept of science when taught by using practical appraoch. So teaching science with using practical way get better achievement than without using practical approach.

By the result of this study, it can be concluded that the practical approach helps to understand the scientific concept clearly to the student rather than traditional method of science teaching. Therefore, using practical approach is effective in teaching science. The problems of science teaching can minimize by different ideas, likewise maintaining the well facilitated science lab in each school, economic and administrative support, increasing the teacher and student interest on practical work, maintaining the teacher and student regularities, including 50 percentage practical course content in the science curriculum. This quasi experimental method was used only purposively selected sample schools at district headquaters of Gorkha district. It would be better to conduct pure experimental method by randomly selecting school from the whole secondary schools of Gorkha district which provide more reliabilty of research and which can be generalised in broad field.

\section{References}

1. Abrahams, I., \& Millar, R. (2008). Practical work: Making it more effective. Getting Practical, 91(334).

2. Abrahams, I. \& Saglam, M.(2010). A study of teachers' views towards practical work in secondary schools in England and Wales. International Journal of Science Education, 32 (06), 753-768. doi. 10.1080/ 09500690902777410

3. Abrahams, I., \& Millar, R. (2008). Does practical work really work? A study of the effectiveness of practical work as a teaching and learning method in school science. International Journal of Science Education, 30 (14), 1945-1969. doi org/10.1080/09500690701749305

4. Ahmad, J. (2009). Teaching of biological sciences, New Delhi: PHI Learning Private Limited.

5. Bhattarai, H. (2066 B.S). Philosophical and sociological foundation of education. Kalimati, Kathmandu Inclusive Publication and Private Limited.

6. Chalmers, A. F. (1982). What is this thing called science? The Open University Press.

7. Creswell, J. W.(2009). Quantitative, qualitative and mixed methods approaches (third edition). New Delhi: Sage.

8. Creswell, J. W.(2012). Educational research: Planning conducting and evaluating quantitative and qualitative research. New Delhi: PHI Learning Private Limited. 
9. Davar, M. (2012): Teaching of science. New Delhi: PHI Learning Pvt. Ltd.

10. Hodson, D. (1990). A critical look at practical work in school science. School Science Review, 70 (256), 33-40.

11. Hodson, D. (2005). Towards research-based practice in the teaching laboratory studies in Science Education. (41)1, 167-177, doi: 10.1080/03057260508560217

12. Isozaki, I. (2017). Laboratory work as a teaching method: A historical case study of the institutionalization of laboratory science in Japan. Espacio, Tiempo y Educación, 4(2), 101-120. doi: http://dx.doi.org/10.14516/ ete. 177

13. Kalra, R. M.; \& Gupta, B. (2012): Teaching of science. New Delhi: PHI Learning Pvt. Ltd..

14. Millar, R. (2004). The role of practical work in the teaching and learning of science. Paper presented at the High School Science Laboratories: Role and Vision. Washington DC: National Academy of Sciences.

15. Mitra, H. (2001). A study on teaching materials and subject wise classroom observation. Research Study, Kathmandu, HMG.

16. Mohan, R. (2010).Innovative science teaching, New Delhi: PHI Learning Private Limited.

17. Muijs, J.(2004). Doing quantitative research in education. London: Sage Publication.

18. Okwoduba, E. N.,\& Okigbo, E. C.(2018). Effect of teaching methods on students' academic performance in chemistry in Nigeria: Meta-analytic review. Bulgarian Journal of Science and Education Policy, 12(2), 418-434.

19. Sharma, R. C. (2010). Modern science teaching. New Delhi: Dhanpat Rai Publishing Company Private Limited.

20. Shrestha, C. B., Tamang, R. L. \& Basnet, S. (2066). Educational psychology. Kathmandu: Bhudipuran Publication.

21. Sood, J. K. (1989). Teaching of science. Chandigrah: Kohli Publishers 